\title{
The Importance of Humor in Teaching
}

\author{
Ying Zhang \\ Yantai Nanshan University \\ Longkou, Shandong, China 265706
}

\begin{abstract}
Humor is a high-level soul and a spiritual activity linking with laughter, entertainment and funny. People often learn the true meaning from laughter. It is known to all that mental problems and illness often come from unpleasant emotional experience. On the contrary, humor can help students develop open-minded and optimistic character in selfreflection, ease the atmosphere and lessen the conflict.
\end{abstract}

Keywords - importance; humor; teaching

\section{INTRODUCTION}

Lenin said: humor is a beautiful, healthy quality. It is a kind of art form. In classroom teaching activities, teachers' humor rich in philosophy and fun could not only bring students wisdom and beauty, but also deeply move and attract students. It could make teaching fun and learning easy. Thus, humor is regarded as a manifestation of maturity. Nowadays, our life is full of sunshine and laughter. With busy work, we could let humor serve as massagist and make our life full of fun in leisure time. The term of humor was first recorded in Chapter $9 \cdot$ Huaisha, written by Qu Yuan. It said: “煦兮查查, 孔静幽默 (shùn x̄̄ yăo yăo, kǒng jìng yōu mò)”. But here, “幽默” means quiet and silence. In this paper, "humor", as an aesthetic category, refers to an amusing and tasty sentiment. It is one method to create happy teaching atmosphere, because it could make classroom atmosphere active and teaching interesting, establish harmonious relationship between teacher and students, and stimulate students get interest in learning.

\section{THE INTRODUCTION OF HUMOR IS THE KEY TO OPEN THE STUDENTS' INTEREST IN LEARNING}

Learning interest is the dynamic source of students' active learning. Confucius said: "people who knows how to study is inferior to people who likes studying; people who likes studying is inferior to people who takes studying as joy". If teachers blindly teach and explain only according to teaching material, it would be boring and make students weary. If teachers could skillfully use humorous language and vivid examples, it could make students laugh and think. Therefore, students could learn knowledge in joyful atmosphere. It can not only reduce students' tiredness but also develop, stimulate and cultivate the enthusiasm of learning.

When I taught College Life I Unit 5 "Information, Please", I introduced this article with one of my story about telephone in college days. It's like this. In a midnight, my dormitory's phone suddenly rang. I slept in lower berth, so I pick up the phone without hesitation. I said: "hello, who do you want to speak to?" Then, the other end of the phone answered strangely, "You!" My heart was trembling and then I asked, "Who is that speaking, please? Who do you want to speak to?" And then I heard a loud voice: "You, I want to speak to you." I immediately hung up the phone. A few seconds later, the phone rang again, and when I asked who was that speaking, she answered, "I am a ghost!" I was scared and immediately threw away the phone. I trembled and buried my head in quilt. When the telephone rang the third time, one roommate picked up the phone and she taught the other side a lesson, and angrily unplugged the phone. At this time, sisters in the dormitory were attracted by the calls. The whole dormitory was filled with a strange air. Then, "the Big Eyes" said, "give me the phone. I do not believe it is really haunted". Suddenly, the phone rang again. It turned out to be a friend of the Big Eyes. She mistook my voice for her voice. The disturbance subsided. At this time the atmosphere in the classroom also follow the story, from "holding the breath", "sighing with relief" to "roaring with laughter". Then I introduced the story of this class "story about telephone".

\section{THE HUMOROUS LANGUAGE IS A BRIDGE TO ESTABLISH HARMONIOUS RELATIONSHIP BETWEEN TEACHERS AND STUDENTS}

Anthropologists' research results show that humor can clear up misunderstanding, lighten atmosphere, eliminate conflicts and reduce anxiety. Suhomalisky, a famous educator of the former Soviet Union, pointed out: "if teachers have no sense of humor, they may build a wall between them and students. Teachers can not understand students, and students also can not understand teachers." Educational research shows that students would reject all requests from teachers if their emotions are opposite to their teachers'. It would hinder them to truly understand the correct meaning of requests, which is the so-called "obstacle of meaning". The humor in teaching is a good medicine to establish harmonious relationship between teachers and students, to eliminate the obstacles of meaning. It can help students experience teachers' beauty in human feelings and virtues in character, so as to shorten the psychological distance between teachers and students, to achieve the effect of "helping students establish close relationship with teachers, trust teachers and believe what they say". In modern concept of teaching, humorous and amiable teachers could win the support of students. On the contrary, strict and 
traditional teachers are not fit to the trend of teaching, gradually lagging behind or sliding to the edge. Therefore, teachers should be implicit, humorous, and mild in teaching and teaching management. Having no sense of humor is sad. The humor in teaching has some general features, such as infection, elegance, intelligence, implication and enlightenment. It has special function in education and the essence is in education. Humor in teaching can never be divorced from education. Humor in teaching is not the purpose of teaching. It is only a means of teaching, so it should serve the teaching and education.

Before I have seen such a self introduction:

"My name is XXX. From this day, we will be friends."

"First I will introduce myself. For my merits, you can summarize slowly. For my shortcomings, I am active and playful. I am fond of playing badminton. Students who are not convinced could have a contest with me after class (laughter). I also have a sick. That is speaking too straightforwardly. If I offend anyone, please forgive me."

"I will tell you the rules in my class. I allow you to doze in my teaching (laughter). If I cannot teach well and ask you not to doze, it is too bullying (loud laughter). I allow you not to listen, or read other books. But you should not make any noise, for it will impact others. If you do not understand, you can ask questions. And you should stand up before asking. I allow you to criticize me, but you should listen to the one who is right (laughter)."

"Do you think, is it OK?" "Yes!" all students answered loudly. Then the teacher said: "I have a temper. If you are in my class, I always like to ask some 'why'. If you cannot answer, I will speak you straightforwardly. If you don't want me to speak you straightforwardly, you should listen to me attentively, diligent in thinking. You should ask yourself some questions and lest you will be puzzled."

"My students, is it OK?"

"Good, that's settled. We have reached an agreement."

Such humorous talk not only explained the rules in class but also reflected the character and talent of the teacher perfectly. It shortened the psychological distance between teachers and students, and effectively built up the harmonious relationship between teachers and students.

Of course, the sense of humor is not born with. It is accumulative. Teachers should first have profound knowledge and extensive social experience. On this basis, teacher can make his/her class full of fun, humor and wisdom, which can help teachers and students establish a harmonious relationship and unify the teaching and the learning. In addition, it could create a relaxed and happy learning atmosphere. In such atmosphere, students could understand, receive and memorize new knowledge in an efficient way.

\section{THE TEACHER'S HUMOR CAN HELP STUdENTS Cultivate Good Personality}

Humor is the concrete manifestation of one's optimistic spirit and cheerful character. It is also a manifestation of one's noble sentiment and perfect personality. Teacher's humor can help students cultivate optimistic and openminded tolerance and enterprising spirit and see life in a new view, enhance students' sense of humor, and further optimize their non-intelligent factors. A person with a sense of humor, can always find the interesting side of things, enjoy the easiness of life, and establish their unique style and have humorous attitude to life. Such a person has an easy contact with others and makes the persons in contact with him (her) could share a relaxed and pleasant atmosphere. Such a person could add glory to life.

\section{A. In Teaching, Humor Can Bring People a Warm, Relaxed and Calm Feeling}

It is implicit and meaningful, exact, seasoned with wit and exact. It contains education in amusement and creates a happy atmosphere for students in learning. Therefore, teachers can use the following ways in teaching:

1) The humorous and implicit language: Implication is a kind of beauty and a kind of art. It is the connotation of teaching language art. Any effective, successful teaching can't be separated from the implicit language art. For example:

- $\quad$ The plain-word profound-meaning method: Liu Zhiji, Historian of the Tang Dynasty, in "Shitong · Xushi" said: "the words are plain and easy, but the meaning is profound and lasting; though the words have already finished, the meaning is not ended". He tells us not to speak all out in narrative and reasoning, and to leave room for listeners or readers thinking. So, the plain-word profound-meaning method is one of language art in teaching.

- The ancient-thing-citing current-thing-explaining method: it means to use ancient things to explain current things in teaching, rather than explaining straightforwardly. The scholars of the Song Dynasty have said that "the language shouldn't be too straightforward; the meaning shouldn't be too shallow; the context shouldn't be revealed; the lasting appeal should not be too short". "The language shouldn't be too straightforward" and "the context shouldn't be revealed" mean that the teaching language should be implicit. Teachers can cite ancient things to explain current things properly. There is an insinuation or implication in the words, so that the teaching language becomes meaningful and infectious. It enables students with an endless aftertaste, and they are willing to receive and accept what teachers teach. The teaching effect will be good.

The circuitous questioning method: this language art uses circuitous questioning to arouse students' emotion swells and leap of rational thinking, so that students can obtain knowledge, understand the good sense and receive 
instruction in the combination of sense and sensibility. The general design of circuitous questioning includes three levels: first is to put questions; second is to guide; the third is to sum up. Go deep step by step, grip the hearts, open minds and touch feelings. Teachers can get twice the effect with half the effort.

The kind and mild method: it is a method for the need of language transfer and conversion. Teachers should teach and organize teaching language mildly and kindly, so that students can experience their kindness and beauty. By using this method, we can make the relationship of teaching and learning harmonious, interlinked and natural, and thus achieve the purpose of optimizing the teaching process and improving the teaching level.

2) Teacher's humor language plays an important role in making class atmosphere active, attracting the attention of students and contributing to the relaxed and happy learning attitude: Facts show that students always like the teachers with a sense of humor. They can build harmonious relationship. However, the humor in teaching is different from the humor in the crosstalk, drama, film and television. Humor in the classroom is a solemn sense of humor. The solemn sense refers to the scientific and serious nature of teaching content. Humor refers to the fun in teaching form and method. Without the solemn sense, humor will lose its basic meaning. Without humor, the solemn sense will lack a lively and interesting form of expression. Its ways include:

Telling jokes: in the teaching process, teachers can tell some philosophical, intellectual and funny jokes in a timely manner. The essence of the teaching process is to persuade, enlighten and educate people, and bring people wisdom and power. It is not necessarily to be so solemn or elegant. Teachers also can talk with students lively and jovially. Empathize in laugh, establish relationship through laugh, persuade and enlighten with laugh, and then bring people wisdom and power. In the process of teaching teachers correctly, cleverly intersperse with jokes, which can make tongue in the cheek and make people think deeply. Moreover, it is conducive to the moral education and communication. For example, when it comes to the word "keen", I refer to such a joke:

Boss: "If you are going to work here, young man, one thing you must learn is that we are very keen on cleanness in this firm. Did you wipe your feet on that mat as you came in?"

\section{Interviewee: "Oh, yes, Sir."}

Boss: "And another thing we are very keen on is truthfulness. There is no mat at all."

Citing allusions: there are a lot of stories in Chinese history. These allusions in fact are means to persuade people. At same time, they contain witty jokes and rich knowledge. It is necessary to make the past serve the present. By citing these allusions, it can not only help students deepen the understanding of knowledge and understand the good sense, but also can convey emotion and create a happy atmosphere.
For example, once some students felt very tired after having several classes. They fell asleep on the desk. At this point, the teacher stopped the lecture and spoke with a witty language: I heard that there was a little penguin. It liked to nestle up its head and long neck against the ground for a while when learning to nest from its master. The master asked: "what do you mean?" The little penguin answered: "this is my courtesy to you." So I was inspired: some students always like to put their heads on the desk. It may also be their courtesy to me! As soon as I stopped, students roared with laughter. A few sleeping students were waken up and felt ashamed.

(3) Inserting with the celebrity anecdotes or two-part allegorical sayings: when give students ideological and moral education, teachers should not only bring out the facts and reasons rigidly. It is advisable to use some celebrity anecdotes or two-part allegorical saying. It can cause students a knowing smile without losing the holiness and elegance of teaching. Meanwhile, it can open students' mind, leave a deep educational track in students' mind and make students unforgettable for lifelong. Take two examples. Nothing is impossible if there is a willing heart. A man without dream is like a bird without wings.

\section{B. If Students Break Rules, Some Teachers May Bitingly Scold the Students and Roughly Rebuke the Students.}

(1) Retreat for the sake of advancing: For students' false behaviors, teachers shouldn't give criticism in hurry. Teachers can pretend to not take it seriously, and then enlighten students and give the students opportunity to make self-examination. The students may recognize their errors by themselves. When a teacher talked about the exercise of pop music, while a student was singing softly in the classroom, the teacher will stop and kindly say: "everybody loves popular songs. Today let's play a game, called 'song relay'. Every student sings a sentence of lyric, but every sentence should be different. Now please think for a while." Then the teacher cast a glace at that student. The student had lowered his head and was aware of his wrong. In the course of the game, this student's attention was very concentrated. When it turned to him, he sang passionately. After one round, the teacher praised the alertness and attentiveness of that student. Since then, the student no longer wandered his mind. If the teacher stopped to criticize the student relentlessly, it would interfere the teaching. This teacher chose a humorous way. The teacher used just a few words, but they are appropriate and kindly. It not only played the function of criticism in a euphemistic way, but also made the student convinced.

(2) Make self-mockery: it is unavoidable for teachers to make mistake in teaching: Students may laugh at it. If teacher criticize the students directly, it seems the teacher is very petty-minded. If the teacher does not care it, it is not a right way to educate students. Self-mockery is a good method at this situation, for it can not only show the teacher's alertness and humor, but also can educate the students. For example, if there is a wrong word in the blackboard writing of teacher, the teacher can ask students to find out the wrong place and correct it. Afterwards, the teacher could say: "this is my carelessness, but you help me 
correct it. I'm very sorry, please forgive me." In this way, the students may learn to be careful in their study.

(3) Guide the students while allowing them to make their own decisions: sometimes the students do not know that they have broken the class rules. Teachers might as well not to disclose it, and use an artful and circuitous way to guide the student. A history teacher came into the classroom, while the students were talking about the exam of last class intensely. They were not aware of the class ring. When he saw this, he didn't angry or started the teaching. He talked with the students and said: "you have taken the chemistry exam just now, right?" "Yes!" the students answered and then their attention was paid to the teacher. The teacher said: "Shouldn't I test you on chemistry, too?" The students looked at the teacher and found the class had begun. The teacher continued: "Lavoisier is a famous chemist. What country is he from?" The students answered "French". The teacher then asked: "how did he die?" The students said: "Lavoisier died in the French Revolution. The Jacobins executed him and charged with the crime of anti-revolution suspicion. The young revolutionary government took a series of harsh dictatorship measures in order to defend the newborn regime." The students felt excited and they were guided to history. The teacher didn't criticize the students directly, and this effect is better than the direct criticism.

\section{CONCLUSION}

Certainly we should know humor is only a means, and it is not the goal. Teachers should grasp the effectiveness of humor in teaching. The teaching content should be harmonious with the humorous expression. Teachers should make creation and artfully employ humor with high aesthetic value and education value according to the nature and needs of teaching content, and make humor effectively serve for education and teaching. If separating from the specific teaching content and practical needs, the blind humor and amusement will go astray. The flexible teaching method can improve the vitality of the classroom teaching. It is a complicated and arduous task. As long as teachers change their ideas, stress the cultivation of students' quality, follow the principle of teaching, pay attention to the ways of teaching and optimize classroom teaching, there will be a qualitative leap in the vitality of classroom teaching.

\section{REFERENCES}

[1] Huang Bo. In Love with Your Class - Humor Education. Secrets for Teacher with Charms. Guangxi Normal University Press, 2007.

[2] Wang Zhe. Humor Education and Students. Sichuan Education Press, 2005.

[3] Li Jinzhong. Benefits of Humor in English Teaching. Science Times. 2004, No. 3: P67-73.

[4] Zhang Yanjuan. The Use of Methods in Teaching. Technology Information. 2005, No. 9: P98-101

[5] Kang Xiuzhen, Bai Fenglan. Report of Times (Academic Edition). January 2012. 